\title{
ICT-Based Lajur Bata Game Media Using Guided Discovery Method on Flat-sided Space Geometry Subject
}

\author{
Lucky Stiardi Rionanda ${ }^{1 凶}$, Farida $^{2}$, Fredi Ganda Putra ${ }^{3}$, Erfina Damayanti ${ }^{4}$, Kenny Candra \\ Pradana $^{5}$ \\ 1,2,3,4 Universitas Islam Negeri Raden Intan, Lampung, Indonesia \\ ${ }^{5}$ Universitas Sang Bumi Ruwa Jurai, Lampung, Indonesia \\ 凶 email: luckystiardi38@gmail.com
}

Received:
14 February
2022
Revised:
24 February
2022
Accepted:
24 February
2022
Published:
28 February
2022

ABSTRACT

This study aims to develop an interactive medium based on ICT with the Guided Discovery method for the Lajur Bata game on the geometry of the flat side space. In this study using research and development procedures through ADDIE model with the following stages: 1) Analysis; 2) Design; 3) Development; 4) Implementation; 5) Evaluation. The Feasibility Test involved 3 Material Experts and 3 Media Experts, while the Attractiveness Test involved 10 students in the Small Scale Trial, and 26 students in the Large Scale Trial. Based on the results of the validation questionnaire, both material experts and media experts have met the "valid" criteria. In the student's response to the feasibility and attractiveness of the brick-line game media, the results of the small-scale student response questionnaire of El-Shihab Islamic Junior High School Bandar Lampung with the "Interesting" criteria. On a large scale, El-Shihab Islamic Junior High School Bandar Lampung with the "Very Interesting" criteria so that the product developed by the researcher is feasible to use.

Keywords: ADDIE; Lajur Bata Games; Flat-sided Space Geometry; Guided Discovery Method; ICT; Research and Development.

\section{INTRODUCTION}

The Corona virus has now spread throughout the world, WHO on March 11, 2020 officially declared Covid-19 a pandemic (Mulkan, 2021). The COVID-19 outbreak has disrupted people's daily lives for the past few months, Including disrupting the education sector (Fatiha \& Nuwa, 2020). This has an impact on the education system from elementary to tertiary levels throughout the country, so the COVID-19 pandemic has disrupted the learning process (Fauziah et al., 2020).

Disruption of the learning process encourages the government to make Physical Distancing policies (Indiani, 2020). This is done to prevent the spread of COVID-19 so that the student learning process is carried out using the learning from home method (Prasetya \& Kundhani, 2021). This makes the use of technology in the world of education is needed. With the use of information technology, teachers or educators are not out of date with the development of the world of education (Widianto et al., 2021). Using technology properly will make education more advanced and developed during 
the COVID-19 pandemic. So that makes technology an important thing in the development of education. The above is one of the educational problems that has always been an interesting topic of discussion among the wider community (Permanasari \& Pradana, 2021). One of the uses of technology in the field of education is as a learning medium.

Learning media is a tool to help the learning process and clarify the meaning in the delivery of learning materials. Learning media is an intermediary tool between educators and students in learning that is able to connect, provide information and distribute messages to create an effective and efficient learning process (Mustaqim, 2016). The use of learning media is an inseparable part and is already an integration of the learning methods used (Kuswanto \& Radiansah, 2018). Learning media often used in schools are human-based media as teachers and print-based media, namely books and worksheets (Purnama et al., 2017). Therefore, innovation is needed to keep up with the times.

Based on observations made at the El-Shihab Islamic Junior High School by giving questionnaires to 26 students about mathematics lessons in the discussion of flat side spaces. The results of the questionnaire show that most students find it difficult to understand the material. The results of interviews with mathematics teachers at the school stated that there was no use of ICT-based learning media in El-Shihab Islamic Junior High School. This is because the learning model at El-Shihab Islamic Junior High School is still not varied, so students are not interested and feel bored in the learning process. So it is necessary to have a learning media that is able to adjust the characteristics of students. This should be a novelty in this school if it can apply learning media in the teaching and learning process.

Media that is in accordance with the problems that occur is media based on Information and communication technologies (ICT), in this case, a computer with multimedia support, can present a non-sequential, nonlinear, and multidimensional text display with branching links and nodes interactively. This view will allow users to choose, synthesize and explain the knowledge they want to know (Suryani, 2016). ducational games are one type of media that functions for the learning process. Increase user knowledge in unique and interesting media contexts. Educational games are also a part of serious games because they contain educational elements (Sitohang et al., 2021). One of the main advantages is that pleasant visualization can activate all students' senses so that incoming stimulation can be easily digested (Sulastri et al., 2022).

There are many kinds of ICT-based game media, that can be developed is the Lajur Bata media. This media has a media concept and the concept of playing which is almost the same as the Super Mario game. Lajur Bata media is a game designed in such a way for junior high school students. This game move generally overcomes challenges through several obstacles to achieve victory. This media game was developed to help students to practice their ability to master the material and count related to the material of flat side spaces (Astuti \& Ulfah, 2019).

So far, learning is teacher-centered (using the lecture method in learning mathematics) so that students are only used as learning objects (Dahlan, 2019). It is 
unlikely that students' abilities can develop if the learning process is like this, Thus, learning should be an environment in which students are actively involved in many useful activities, students must be active in learning, not just copying or following examples without knowing their meaning (Listanti, 2015). One of the student-centered learning is the discovery method. The guided discovery model is one of the learning models that allow teachers to act as complete mentors and facilitators and make students learn to be more focused on achieving the goals set (Tias, 2017). The discovery in question is that students find concepts through guidance and direction from the teacher, because, in general, most students still need basic concepts to be able to find something (Listanti, 2015).

The Guided Discovery Method is a teaching method that seeks to lay the groundwork and develop scientific thinking. Students are placed as learning subjects. In this method, the teacher acts as a facilitator in solving a given problem (Rhamayanti, 2019). Guided discovery learning is learning where students are given a situation or problem, which then collects data, makes guesses, tries (trial and error), seeks and finds regularities (patterns), generalizing or compiling formulas along with general forms, proving whether or not the conjecture is true (Batubara, 2020). Guided Discovery allows students to be actively involved in preliminary learning and improve problem-solving skills, while learning materials last longer because students are engaged in the exploratory process.

Previously, similar studies have been conducted, including Astuti \& Ulfah (2019) regarding the development of the lajur bata game media, the feasibility of the experts, and students' responses to the development of the lajur bata game media on the flat build material. The results stated that the Lajur Bata game media was feasible and very interesting and helped students in learning mathematics, especially in the area of perimeter and area of flat shapes (squares, rectangles, and triangles) (Astuti \& Ulfah, 2019). Research by Abdul Rosyid (2018) regarding the development of mathematics learning media in the form of a ninja algebra mobile game based on edutainment for class VIII junior high school states that there is an increase in student learning in mathematics after the development of learning media in the form of a ninja algebra mobile game (Rosyid, 2018). Research by Ningrum, et al (2021) Research by Ningrum, et al. regarding the effect of the Problem Based Learning Model Assisted by the Papan Kompetisi Bangun Datar (Pakom Bantar) Media Towards Understanding Mathematical Concepts. The results of the study stated that the Media-assisted Problem Based Learning model had a significant effect on understanding mathematical concepts in the theory of perimeter and area of flat shapes (Ningrum et al., 2021). And the Last but not least, Research by Ulfa, et al. (2017) regarding the difference between students' mathematical problem-solving abilities in guided discovery learning for video learning and conventional learning models. The results of the study stated that there were differences in the average mathematical problem-solving abilities of students who used the guided discovery learning model for video learning compared to those using conventional learning. (Ulfa et al., 2017). 
From previous research, there has been no research on the development of ICTbased Lajur Bata game media using the Guided Discovery method on Flat Sided Space Geometry. So based on the description above, this study aims to develop an ICT-based Lajur Bata Game Media with Guided Discovery Method on flat-sided geometry material with Practical, Efficient and Effective Properties.

\section{METHOD}

This research is included in the type of research and development research. This research was conducted at El-Shihab Islamic Junior High School Bandar Lampung. The subjects of this study were students of class VIII. Data collection techniques used are interviews and questionnaires. The data analysis technique used is the feasibility test and the attractiveness test. This research refers to the development design with the ADDIE approach (Analysis, Design, Development, Implementation, Evaluation). The game media was developed using the Construct 2 software. The Feasibility Test involved 3 Material Experts and 3 Media Experts, while the Attractiveness Test involved 10 students in the Small Scale Trial, and 26 students in the Large Scale Trial.



Figure 1. ADDIE Development Process (Ghani \& Daud, 2018)

The questionnaire used is a validation questionnaire to media experts, material experts, and students' attractiveness test questionnaire. The qualitative data is obtained from the advice and input of experts, while the quantitative data is obtained from the results of validation and student responses. The assessment of the percentage of validation results and student responses is obtained using the formula:

$\bar{x}=\frac{\sum_{i=1}^{n} x_{i}}{n}$ with $\quad x i=\frac{\text { Total score }}{\text { Max score }} \boldsymbol{4} 4$

Description :

$\bar{x}=$ Final average score

$x_{i}=$ The value of the student's answer score

$n=$ number of respondents 
Table 1. Scoring Score (modified)

\begin{tabular}{cc}
\hline Score & Eligibility Answer Options \\
\hline 4 & Very Good \\
3 & Good \\
2 & Not Good \\
1 & Not Very Good \\
\hline
\end{tabular}

Table 2. Interpretation of Expert Validation Assessment Criteria (modified)

\begin{tabular}{ccc}
\hline Quality Score & Eligibility Criteria & Description \\
\hline $3,26<\bar{x} \leq 4,00$ & Valid & No Revision \\
$2,51<\bar{x} \leq 3,26$ & Quite Valid & Partial Revision \\
$1,76<\bar{x} \leq 2,51$ & Less Valid & Partial Revision \& Material Review \\
$1,00<\bar{x} \leq 1,76$ & Invalid & Total Revision \\
\hline
\end{tabular}

Table 3. Trial Criteria Interpretation (modified)

\begin{tabular}{cc}
\hline Quality Score & Attractiveness Criteria \\
\hline $3,19<\bar{x} \leq 4,00$ & Very Attractive \\
$2,51<\bar{x} \leq 3,19$ & Attractive \\
$1,76<\bar{x} \leq 2,5$ & Less Attractive \\
$1,00<\bar{x} \leq 1,76$ & Not attractive \\
\hline
\end{tabular}

\section{FINDINGS AND DISCUSSION}

Research conducted at El-Shihab Islamic Junior High School Bandar Lampung has facilities that support the application of learning media but are not optimal in its use. According to the ADDIE development design, this research was carried out in various stages.

\section{First Stage: Analysis}

There are several stages of analysis, and the first is a needs analysis. Field analysis or observation is carried out in this needs analysis by conducting interviews. Interviews were conducted with Mrs. Umi Yuliana Putri, S.Pd; he stated that learning at El-Shihab Islamic Junior High School had been going well. It was just not optimal. The learning process still does not use technology as a learning medium, and Although a special room has been provided for a computer lab, it is usually only used for introductions to computers and displaying PowerPoint slides. Finally, she advised that it would be better if there were digital-based learning media, and she fully supports the researchers' efforts to develop ICT-based game media products using the guided discovery learning method. The needs analysis results based on a questionnaire filled out by 26 students show-that 
there is still a lack of student interest in learning mathematics. So we need a variety of learning media in the learning process to further increase student interest in learning.

The second stage in the analysis stage is curriculum analysis. Curriculum analysis is a reference in the form of basic competencies which is a research and development center. The selected subject matter is Flat-sided Space Geometry material in class VIII. The next stage is the analysis of the characteristics of students.

Based on the results obtained from observations of teachers who teach mathematics subjectsinformation was obtained that the problems that occurred in some students in the mathematics learning process were caused by the students not having mastered the prerequisite material, seperti materi bangun ruang sisi datar dimana materi tersebut such as Flat-sided Space Geometry material, where the material requires an understanding of formulas and accuracy in terms of multiplication. The teaching materials used are only textbooks from schools.

\section{Second Stage: Design}

After analyzing, the researchers compiled mathematics learning media in the form of ICT-based Lajur Bata educational games adapted to the basic competencies contained in the 2013 curriculum. There are several stages, such as preparing the game framework, material design, and instrument design. Here is what the game framework looks like:

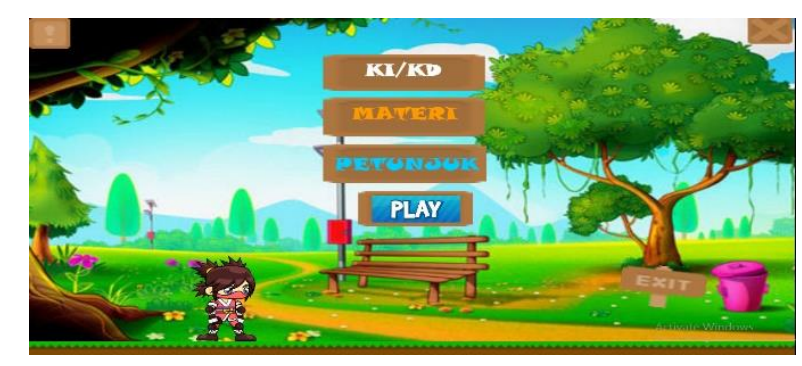

Figure 2. Initial View of Educational Games

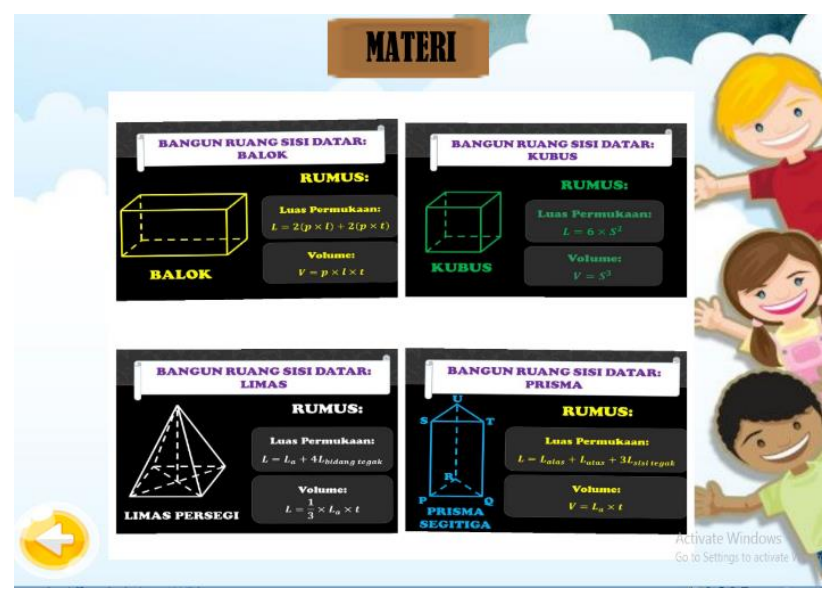

Figure 3. Material Section In Game 


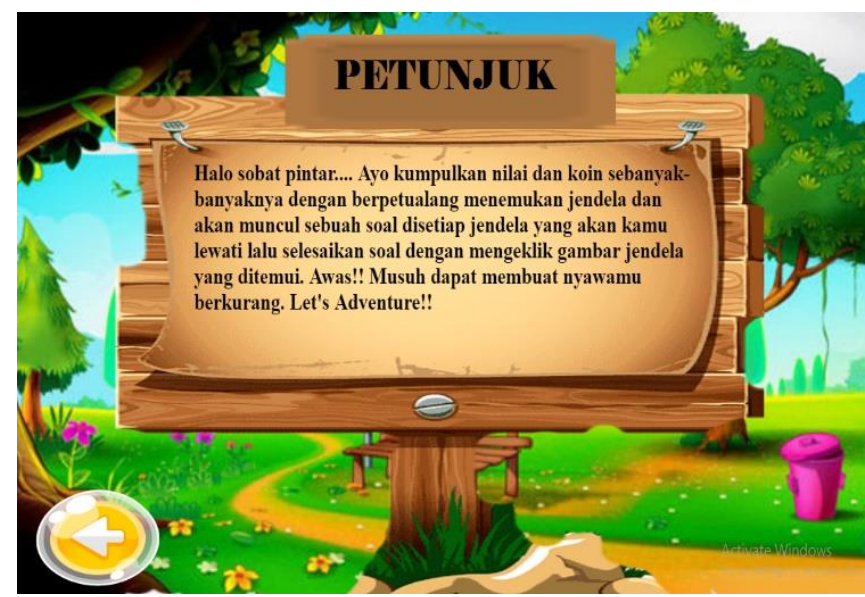

Figure 4. Game Hint Display



Figure 5. Display On Game

\section{Third Stage: Development}

A feasibility test is carried out by media experts and material experts at this stage.

\section{Material Expert Validation Results}

Material expert validation is carried out to determine the suitability of the material, the correctness of the language and the correctness of the order of the material. In the material validation, 3 aspects are assessed, namely the Content Eligibility, Serving Eligibility, and-implementation aspect. In material validation, there are 2 stages. The first stage is the initial use of the validation carried out, the second stage is after revisions have been made in accordance with suggestions and input from material experts.

Table 4. The Results of the Validation of the First Stage Material Expert

\begin{tabular}{cccccc}
\hline \multirow{2}{*}{ Item } & \multirow{2}{*}{ Aspect } & \multirow{2}{*}{ Analysis } & \multicolumn{3}{c}{ Validator } \\
\cline { 3 - 6 } & Content Eligibility & $\sum$ Sscore & 12 & 13 & 10 \\
& & Max Score & 16 & 16 & 16 \\
& $\chi \mathrm{x}$ & 3 & 3.2 & 2.5 \\
& $\chi$ & & 2.9 & Quite Valid \\
\hline
\end{tabular}




\begin{tabular}{|c|c|c|c|c|c|}
\hline 2 & Serving Eligibility & SScore & 26 & 28 & 30 \\
\hline \multirow{3}{*}{3} & \multirow{3}{*}{ Implementation Aspect } & $\begin{array}{c}\text { Max Score } \\
\chi i \\
\chi \\
\text { Criteria }\end{array}$ & $\begin{array}{l}36 \\
2.8\end{array}$ & $\begin{array}{c}36 \\
3.1 \\
3.0 \\
\text { Quite Valid }\end{array}$ & $\begin{array}{l}36 \\
3.3\end{array}$ \\
\hline & & $\sum$ Score & 3 & 3 & 3 \\
\hline & & $\begin{array}{c}\text { Max Score } \\
\chi \mathrm{i} \\
\chi \\
\text { Criteria } \\
\end{array}$ & $\begin{array}{l}4 \\
3\end{array}$ & $\begin{array}{l}\quad 4 \\
\quad 3 \\
3.0 \\
\text { Quite Valid }\end{array}$ & $\begin{array}{l}4 \\
3\end{array}$ \\
\hline \multirow{2}{*}{\multicolumn{3}{|c|}{ Total average }} & \multirow{2}{*}{\multicolumn{3}{|c|}{$\frac{2.9}{2 \text { Oite Valid }}$}} \\
\hline & & & & & \\
\hline
\end{tabular}

Based on the material expert validation results, it was found that the three aspects assessed by the criteria were "quite valid". The following is a graph of the assessment of the results of the first stage material expert validation:

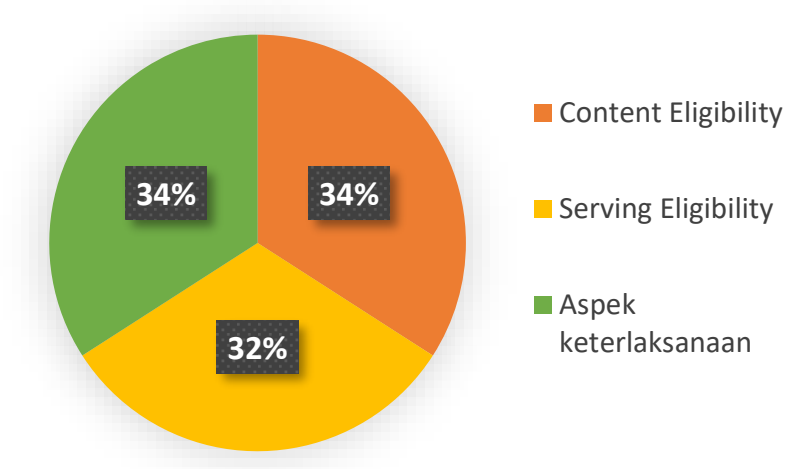

Figure 6. Stage 1 validation results by Material Expert

Based on the results shown in table 4 , it is necessary to revise. In this case, the researcher made a revision according to the suggestions of the material expert validators, After the revision, the stage II assessment was carried out by the validators and obtained the results of the second validation below.

Table 5. Second Stage Material Expert Validation Results

\begin{tabular}{|c|c|c|c|c|c|}
\hline \multirow{2}{*}{ Item } & \multirow{2}{*}{ Aspect } & \multirow{2}{*}{ Analysis } & \multicolumn{3}{|c|}{ Validator } \\
\hline & & & V1 & $\mathrm{V} 2$ & V3 \\
\hline 1 & Content Eligibility & Sscore & 15 & 13 & 15 \\
\hline & & $\begin{array}{c}\text { Max Score } \\
\chi \mathrm{i} \\
\chi \\
\text { Criteria }\end{array}$ & $\begin{array}{l}16 \\
3.7\end{array}$ & $\begin{array}{c}16 \\
3.2 \\
3.5 \\
\text { Valid }\end{array}$ & $\begin{array}{l}16 \\
3.7\end{array}$ \\
\hline 2 & Serving Eligibility & $\sum$ Score & 34 & 30 & 35 \\
\hline & & $\begin{array}{c}\text { Max Score } \\
\chi i \\
\chi \\
\text { Criteria }\end{array}$ & $\begin{array}{l}36 \\
3.7\end{array}$ & $\begin{array}{c}36 \\
3.3 \\
3.6 \\
\text { Valid }\end{array}$ & $\begin{array}{l}36 \\
3.8\end{array}$ \\
\hline 3 & Implementation Aspect & $\sum$ Score & 4 & 3 & 4 \\
\hline
\end{tabular}




\begin{tabular}{ccccc}
\hline & Max Score & 4 & 4 & 4 \\
& $\chi \mathrm{i}$ & 4 & 3 & 4 \\
& $\chi$ & & 3.6 & \\
& Criteria & & Valid & \\
\hline Total average & & 3.5 \\
\hline Criteria & & Valid \\
\hline
\end{tabular}

From table 5 it can be seen that the results of the revision received a positive response by the Phase II material validators because there was an increase in the value of each aspect which initially only received the criteria of "quite valid" to "valid". The following graph shows the results of the second stage of material expert validation:

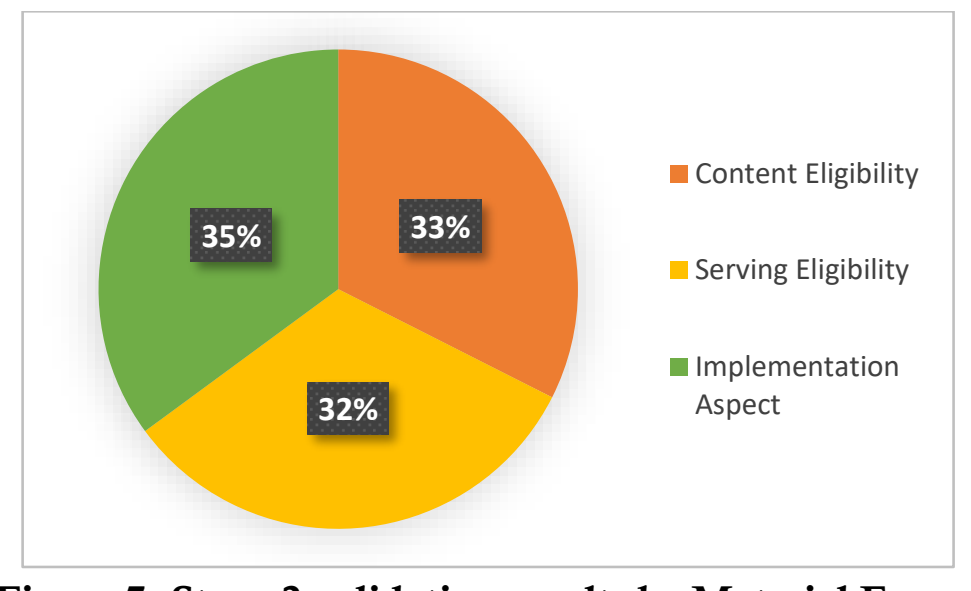

Figure 7. Stage 2 validation results by Material Expert

\section{Media Expert Validation Results}

Material expert validation is carried out to determine the suitability of the material, the correctness of the language and the correctness of the order of the material. Invalidating the material, there are 3 aspects assessed: Artistic and aesthetics, ease of navigation, and overall function. In material validation, there are 2 stages. The first stage is the initial use of the validation carried out, the second stage is after the revision is carried out in accordance with the suggestions and input from media experts.

Table 6. First Stage Media Expert Validation Results

\begin{tabular}{|c|c|c|c|c|c|}
\hline \multirow[b]{2}{*}{ Item } & \multirow[b]{2}{*}{ Aspect } & \multirow[b]{2}{*}{ Analysis } & \multicolumn{3}{|c|}{ Validator } \\
\hline & & & V1 & $\mathrm{V} 2$ & $\mathrm{~V} 3$ \\
\hline \multirow[t]{5}{*}{1} & \multirow[t]{5}{*}{ Artistics and Aesthetics } & SScore & 16 & 18 & 21 \\
\hline & & Max Score & 24 & 24 & 24 \\
\hline & & $\chi \mathrm{i}$ & 2.6 & 3 & 3.5 \\
\hline & & $\chi$ & \multirow{2}{*}{\multicolumn{3}{|c|}{$\begin{array}{c}3.0 \\
\text { Quite Valid }\end{array}$}} \\
\hline & & Criteria & & & \\
\hline \multirow[t]{4}{*}{2} & \multirow[t]{4}{*}{ Ease of Navigation } & $\sum$ Score & 15 & 16 & 18 \\
\hline & & $\overline{\text { Max Score }}$ & 20 & 20 & 20 \\
\hline & & $\chi \mathrm{i}$ & 3 & 3.2 & 3.6 \\
\hline & & $x$ & & 2.8 & \\
\hline
\end{tabular}




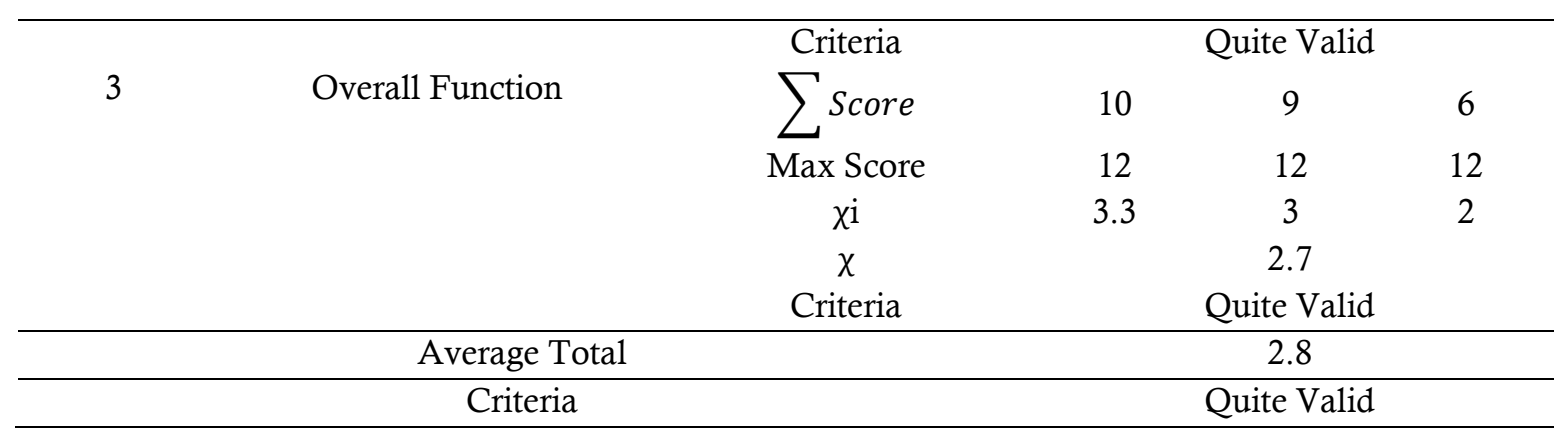

Based on table 6, the first stage of media expert validation results obtained the "quite valid" criteria for all assessed aspects. The following is a graph of the results of the first stage of media expert validation:

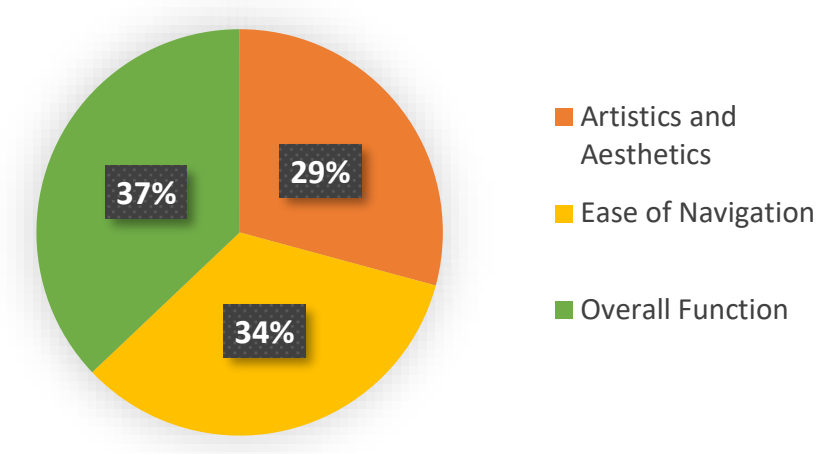

Figure 8. Stage 1 validation results by Media Expert

From the results of media expert validation in stage 1, the guided discovery learning game media still needs to be revised. The following are the results of the second stage of media expert validation:

Table 7. Second Stage of Media Expert Validation Results

\begin{tabular}{|c|c|c|c|c|c|}
\hline \multirow{2}{*}{ Item } & \multirow{2}{*}{ Aspect } & \multirow{2}{*}{ Analysis } & \multicolumn{3}{|c|}{ Validator } \\
\hline & & & V1 & $\mathrm{V} 2$ & V3 \\
\hline \multirow[t]{5}{*}{1} & Artistics and Aesthetics & S Score & 22 & 20 & 23 \\
\hline & & Max Score & 24 & 24 & 24 \\
\hline & & $\chi \mathrm{i}$ & 3.6 & 3.3 & 3.8 \\
\hline & & $\chi$ & & 3.5 & \\
\hline & & Criteria & & Valid & \\
\hline \multirow[t]{5}{*}{2} & Ease of Navigation & $\sum$ Score & 18 & 17 & 19 \\
\hline & & Max Score & 20 & 20 & 20 \\
\hline & & $\chi \mathrm{i}$ & 3.6 & 3.4 & 3.8 \\
\hline & & $\chi$ & & 3.6 & \\
\hline & & Criteria & & Valid & \\
\hline \multirow[t]{3}{*}{3} & Overall Function & $\sum$ Score & 11 & 10 & 12 \\
\hline & & Max Score & 12 & 12 & 12 \\
\hline & & $\chi \mathrm{i}$ & 3.6 & 3.3 & 4 \\
\hline
\end{tabular}




\begin{tabular}{ccc}
\hline & $\chi$ & 3.6 \\
& Criteria & Valid \\
\hline Average Total & & 2.8 \\
\hline Criteria & & Quite Valid \\
\hline
\end{tabular}

All aspects obtained "valid" criteria. Based on table 7, there is a significant increase in the value of each aspect. Because the media that is judged to have met the valid criteria by both the validation of material experts and media experts, it can be continued to the next stage, namely the Implementation stage.

\section{Fourth Stage: Implementation}

The already feasible media is then tested at the El-Shihab Islamic Junior High School. The product trial was carried out in two stages; namely, the first stage (small scale) was carried out by 10 students, and 26 students carried out the second phase (large scale). Product trials are applied during the mathematics learning process. When students start learning by using the Lajur Bata game media, students are introduced to the material listed in the game. Then students are given instructions before starting the game. When the students understand, then the game begins. After completion, students were given a questionnaire to give their responses about the game media used. The results obtained from these trials can be explained as follows.

\section{Small-Scale Trial}

The small group trial was implemented at the El-Shihab Islamic Junior High School, involving 10 students. The following are the results of a small group trial questionnaire.

Table 8. Small-Scale Trial Results

\begin{tabular}{cccccccccccccc}
\hline \multicolumn{110}{c}{ Question Number } & Total \\
\hline 1 & 2 & 3 & 4 & 5 & 6 & 7 & 8 & 9 & 10 & 11 & 12 & \\
\hline 3,1 & 3,1 & 3 & 3,1 & 3 & 3,1 & 3,2 & 3,1 & 3 & 3 & 3,1 & 3,1 & 3 \\
inter & inter & inter & inter & inter & inter & Very & inter & inter & inter & inter & inter & inter \\
estin & estin & estin & estin & estin & estin & inter & estin & estin & estin & estin & estin & estin \\
$\mathrm{g}$ & $\mathrm{g}$ & $\mathrm{g}$ & $\mathrm{g}$ & $\mathrm{g}$ & $\mathrm{g}$ & $\mathrm{es}$ & $\mathrm{g}$ & $\mathrm{g}$ & $\mathrm{g}$ & $\mathrm{g}$ & $\mathrm{g}$ & $\mathrm{g}$ \\
\hline
\end{tabular}

\section{Large-Scale Trial}

After testing in small groups, the researchers proceed to large groups to know the broad appeal of the product. Respondents in this large-scale trial included 26 students. The following are the results of large group trials.

Table 8. Large-Scale Trial Results

\begin{tabular}{ccccccccccccc}
\hline \multicolumn{11}{c}{ Question Number } & Total \\
\hline 1 & 2 & 3 & 4 & 5 & 6 & 7 & 8 & 9 & 10 & 11 & 12 & \\
\hline 3,46 & 3,58 & 3,46 & 3,54 & 3,46 & 3,46 & 3,69 & 3,65 & 3,65 & 3,5 & 3,5 & 3,5 & 3,54 \\
\hline
\end{tabular}




\begin{tabular}{ccccccccccccc}
\hline Very & Very & Very & Very & Very & Very & Very & Very & Very & Very & Very & Very & Very \\
inter & inter & inter & inter & inter & inter & inter & inter & inter & inter & inter & inter & inter \\
estin & estin & estin & estin & estin & estin & estin & estin & estin & estin & estin & estin & estin \\
$\mathrm{g}$ & $\mathrm{g}$ & $\mathrm{g}$ & $\mathrm{g}$ & $\mathrm{g}$ & $\mathrm{g}$ & $\mathrm{g}$ & $\mathrm{g}$ & $\mathrm{g}$ & $\mathrm{g}$ & $\mathrm{g}$ & $\mathrm{g}$ & $\mathrm{g}$ \\
\hline
\end{tabular}

The results of the questionnaire showed that the mathematics learning media in the form of ICT-based Lajur Bata game media with the Guided Discovery method on the subject of flat-sided space was very interesting.

\section{Fifth Stage: Evaluation}

The results of product trials that have been revised based on the advice of experts, researchers get responses from teachers and students that the product that researchers have developed is good and feasible to use (very interesting). Based on the results of the product revision, according to input and criticism from several validators, the product is ready to be tested. Then it can be concluded that Lajur Bata game media with the Guided Discovery method on the subject of flat-sided space at the El-Shihab Islamic Junior High School in Bandar Lampung has been completed.

\section{CONCLUSION}

This research and development resulted in a product developing ICT-based Lajur Bata game media with the guided discovery method on the subject of flat-sided spaces at the El-Shihab Islamic Junior High School Bandar Lampung. Based on the results of the validation questionnaire, both material experts and media experts have met the "valid" criteria. In the student's response to the feasibility and attractiveness of the Lajur Bata game media, the results of the small-scale student response questionnaire of El-Shihab Islamic Junior High School Bandar Lampung with the "Interesting" criteria. El-Shihab Islamic Junior High School Bandar Lampung with the "Very Interesting" criteria on a large scale. So, the product developed by the researcher is feasible to use.

\section{REFERENCES}

Astuti, R. D., \& Ulfah, A. (2019). Pengembangan Media Permainan Lajur Bata (Langkah Juara Bangun Datar) Untuk Materi Keliling dan Luas Bangun Datar Kelas 4 Sekolah Dasar. Fundamental Pendidikan Dasar, 1(1), 1-12.

Batubara, I. H. (2020). Peningkatan Kemampuan Pemecahan Masalah Matematik Melalui Metode Penemuan Terbimbing Berbantuan Software Geogebra. Journal Mathematics Education Sigma, 24-28. http://jurnal.umsu.ac.id/index.php/jmes/article/view/4015

Dahlan, A. H. (2019). Pengembangan Model Pembelajaran Pendidikan Matematika Realistik Indonesia (PMRI) Untuk Meningkatkan Ketertarikan Belajar Matematika. JUPITEK: Jurnal Pendidikan Matematika, 1(1), 8-14. https://doi.org/10.30598/jupitekvol1iss1pp8-14

Fatiha, N., \& Nuwa, G. (2020). Kemerosotan Moral Siswa Pada Masa Pandemic Covid 19: Meneropong Eksistensi Guru Pendidikan Agama Islam. Atta'dib Jurnal Pendidikan Agama Islam, 1(2), 1-17. 
Fauziah, F., Neviyarni, N., Karneli, Y., \& Netrawati, N. (2020). Modifikasi Konseling Kelompok Untuk Siswa Dengan Pendekatan Rational Emotive Behavior Therapy (REBT) di Tengah Pandemi Covid-19. Consilium: Berkala Kajian Konseling Dan Ilmu Keagamaan, 7(2), 52-59. https://doi.org/10.37064/consilium.v7i2.7745

Ghani, M. T. A., \& Daud, W. A. A. W. (2018). Adaptation of ADDIE instructional model in developing educational website for language learning. Global Journal AlThaqafah, 8(2), 7-16.

Indiani, B. (2020). Mengoptimalkan proses pembelajaran dengan media daring pada masa pandemi covid-19. Sipatokkong BPSDM Sulawesi Selatan, 1(3), 227-232.

Kuswanto, J., \& Radiansah, F. (2018). Media Pembelajaran Berbasis Android Pada Mata Pelajaran Sistem Operasi Jaringan Kelas XI. Jurnal Media Infotama, 14(1), 15-20. https://doi.org/10.37676/jmi.v14i1.467

Listanti, L. (2015). Pengembangan Media Pembelajaran Flash Berbasis. Chemistry in Education, 4(2252).

Mulkan, H. (2021). Penegakan Hukum terhadap Tindakan Penyalahgunaan Kekuasaan dalam Kondisi Darurat Covid-19. Jurnal Ilmiah Universitas Batanghari Jambi, 21(2), 685-688. https://doi.org/10.33087/jiubj.v21i2.1471

Mustaqim, I. (2016). Pemanfaatn Augmented reality Sebagai Media Pembelajaran. Jurnal Pendidikan Teknologi Dan Kejuruan, 13(2), 728-732. https://doi.org/10.1109/SIBIRCON.2010.5555154

Ningrum, E. F., Bintang, A., Pradana, A., \& Hajron, K. H. (2021). Pengaruh Model Pembelajaran Problem Based Learning Berbantuan Media Papan Kompetisi Bangun Datar (Pakom Bantar ) Terhadap Pemahaman Konsep Matematika. The 14th University Research Colloqium 2021, 1199-1211.

Permanasari, L., \& Pradana, K. C. (2021). Model Pembelajaran Active Knowledge Sharing Terhadap Hasil Belajar Matematika Siswa SMP. Ensiklopedia: Jurnal Pendidikan Dan Inovasi Pembelajaran Saburai, 1(1), 1-7.

Prasetya, M. A. W., \& Kundhani, E. Y. (2021). Learning From Home Selama Pandemi Covid-19 (Studi Kasus Orang Tua Dan Guru). EduHumaniora | Jurnal Pendidikan Dasar Kampus Cibiru, 13(2), 142-152. https://doi.org/10.17509/eh.v13i2.30353

Purnama, R., Sesunan, F., \& Ertikanto, C. (2017). Pengembangan Media Pembelajaran Mobile Learning Berbasis Android Sebagai Suplemen Pembelajaran Fisika SMA Pada Materi Usaha Dan Energi. Jurnal Pembelajaran Fisika Universitas Lampung, 5(4).

Rhamayanti, Y. (2019). Peningkatan Hasil Belajar Matematika dan Respon Siswa Melalui Pembelajaran Kooperatif Tipe STAD dengan Metode Penemuan Terbimbing. Edumatika: Jurnal Riset Pendidikan Matematika, 2(1), 29. https://doi.org/10.32939/ejrpm.v2i1.244

Rosyid, A. (2018). Pengembangan Media Pembelajaran Matematika Berupa Mobile Game Ninja Aljabar Berbasis Edutainment Kelas VIII SMP [UIN Raden Intan Lampung]. http://repository.radenintan.ac.id/id/eprint/4045\%0Ahttp://repository.radenin tan.ac.id/4045/1/SKRIPSI FULL.pdf

Sitohang, G. J., Sumiati, A., \& Susanti, S. (2021). Effect of Problem Based Instruction 
Model Based on Learning Video and Educational Games Media on the Self Efficacy of Students of Class X SMK N 17 Jakarta. Journal Corner of Education, Linguistics, and Literature, 1(2), 106-113. https://doi.org/10.54012/jcell.v1i2.9

Sulastri, S., YL, S., \& Nurhasanah, N. (2022). Utilization of Educational Games in the Implementation of Strengthening Character Education. Journal Corner of Education, Linguistics, and Literature, 1(3), 148-156. https://doi.org/10.54012/jcell.v1i3.32

Suryani, N. (2016). Pengembangan Media Pembelajaran Berbasis ICT. Prosiding Seminar Nasional Teknologi Pendidikan. https://doi.org/10.36781/tarbawi.v6i1.2970

Tias, I. W. U. (2017). Penerapan Model Penemuan Terbimbing Untuk Meningkatkan Hasil Belajar Ipa Siswa Sekolah Dasar. DWIJA CENDEKIA: Jurnal Riset Pedagogik, 1(1), 50-60. https://doi.org/10.20961/jdc.v1i1.13060

Ulfa, K., Buchori, A., \& Murtianto, Y. H. (2017). Efektivitas Model Guided Discovery Learning untuk Video Pembelajaran dalam Mengetahui Perbedaan Kemampuan Pemecahan Masalah Matematika Siswa. MUST: Journal of Mathematics Education, Science and Technology, 2(2), 267. https://doi.org/10.30651/must.v2i2.888

Widianto, E., Husna, A. A., Sasami, A. N., Rizkia, E. F., Dewi, F. K., \& Cahyani, S. A. I. (2021). Pemanfaatan Media Pembelajaran Berbasis Teknologi Informasi. Journal of Education and Teaching, 2(2), 213-224. 